\title{
Does Indian Stock Market Rely on other Asian Stock Markets?
}

\author{
Dr. Amalendu Bhunia ${ }^{1}$, Soumya Ganguly ${ }^{2}$ \\ ${ }^{1}$ Associate Professor \& Head, Department of Commerce, University of Kalyani, West Bengal \\ ${ }^{2}$ Faculty member, Department of Commerce, Barrack pore Rastraguru Surendranath College, West Bengal
}

\begin{abstract}
The present study investigates the relationship between selected Asian eight countries stock market index and Indian stock market BSE-Sensex. In other words, the main objective of the study is whether Indian stock market index is influenced by selected Asian countries stock market or not. The progressive deletion of constraints, reduction of controls over capital movements, quick development of worldwide trade in commodities, services and financial assets, emergence of new capital markets and the upshots of financial and economic crises enhanced the significant dependability among the emerging stock markets as well. This study is based on secondary time series data obtained from index mundi database and yahoo.com database for the period from 1991 to 2013. In the course of analysis, ADF unit root test, co-integration test and causality test have been designed. Johansen multivariate co-integration test shows that Indian stock market index is related with selected eight countries stock market index in the long-run. Granger causality test illustrates that bi-directional causality exists between the selected variables between the selected stock market indices.
\end{abstract}

Keywords: Stock market, India, other Asian countries, unit root test, co-integration test, Granger causal test.

\section{INTRODUCTION}

Over the decade of 1990s, a series of measures in the stock markets were taken. With the automation and liberalization of the Indian stock markets, there has been a distinguishable change in the Indian Stock market towards the later part of the 1990s. Trading system in Bombay Stock Exchange (BSE) and National Stock Exchange (NSE) has reached an international paradigm (Chattopadhyay and Behera, 2006, p. 2). This has formed on a national scale trading method to facilitate gives the same way in to every investors despite environmental position (Joshi, 2011). In that logic, technology has brought about equality among the investors across the country. The stock markets established the best probable schemes practised in advanced stock markets, viz., electronic trading method, dematerialisation of shares, replacement of the Indian carry forward trading system by the index-based and scripbased futures and options; adoption of risk management system etc (Madhusoodhan, 2010). With the introduction of these advanced practices transparency has also increased in the stock market. As of now, India is allowed to invest in all categories of securities traded in the primary and secondary segments and in the derivative segment (Chattopadhyay and Behera, 2006, p. 6). In economic literature the issues related to stock market integration and comovements of stock prices across countries have received considerable attention. The financial market's integration in general implies that in absence of administrative and informational barriers, risk adjusted returns on assets of the same tenor in each segment of the market should be comparable to one another. Recent globalization and free movements of capital across boundaries of nation have integrated financial market worldwide. Technological innovations have improved market assimilation. Vigilant assessment of global stock market movements in recent years suggests that there exists a substantial degree of interdependence among national stock markets (Joshi, 2011). It is quarrelled that unanticipated expansion in international stock markets seem to have become important "news" that influences domestic stock markets (Eun \& Shim, 1989). This research work has been categories in the following four segments; first segment is about the review of related literature, the second segment deals with the materials and methods carried out for this study. The third segment is the analysis of empirical results and the final segment followed by the conclusion of the research work.

\section{REVIEW OF LITERATURE}

The interest in studying the dynamic relationships among the world's equity markets gathered considerable momentum following the October 1987 global stock market crash, and even more so, following the Asian financial

\footnotetext{
${ }^{1}$ Corresponding Author: bhunia.amalendu@gmail.com
} 
crisis in 1997. Several researchers have examined the relationships among the major developed equity markets and markets in the Asian region. Bailey and Stulz (1990) investigated the prospects for international portfolio diversification among pacific basin stock markets using the daily returns for the Malaysia, Korea, Singapore Hong Kong, Japan, Philippines, Taiwan and Thailand market indices from January 1977 to December 1985. They used simple correlation analysis to detect interrelations among the markets. Their results showed that the degree of correlation between US and Asian equity returns depended upon the time period design. Bhattacharya and Samantha (2001) and Joshi (2011) investigated the extent to which news on NASDAQ helped price formation at the beginning and at the end of a trading day at the Indian bourses using daily data of stock price indices from 2000 (January 3) to 2000 (October 31). They examined the impact of NASDAQ on SENSEX through Ordinary Least Square (OLS) equations under co-integration and error correction outline. The study showed that the news on NASDAQ had played an important role in price formation at the beginning of the new trading day at the Indian bourses. Consequently, this study recommended the assimilation of the Indian capital market with the US market. Wong et al (2004) and Harper et al (2013) investigated the long-run equilibrium relationship and short-run dynamic linkage between the Indian stock market and the stock markets in major developed countries (United States, United Kingdom and Japan) after 1990 using the Granger causality and co-integration method. Using weekly closing prices data from January 1, 1991 to December 31, 2003, they found that Indian stock market was integrated with mature markets. Ahmad, Ashraf and Ahmed (2005) examined the inter-linkages and causal relationship between the NASDAQ composite index in the US, the Nikkei in Japan with that of NSE Nifty and BSE SENSEX in India using daily closing data from January 1999 to August 2004. The study used Granger Causality and Johansen cointegration methods to examine short run and long term relationship among the stock markets respectively. The results of Co-integration test revealed that there was no long-term relationship of the Indian equity market with that of the US and Japanese equity markets. Granger causality test suggested that there was a unidirectional relationship from NASDAQ and Nikkei to Indian stock markets, as supported in Joshi (2011). Bose (2005) identified that the Indian stock market did not function in relative isolation from the rest of Asia and the US as stock returns in India were highly correlated with returns in the US, Japan, as well as other Asian markets during the post-Asian crisis and up to mid-2004. Lamba (2005) performs a comprehensive large sample analysis to investigate the presence of long run relationships among South Asian equity markets and the developed equity markets. The results reveal that Indian markets are influenced by developed equity market of US, UK and Japan. Chen, Lobo and Wong (2006) examined the relation between India-US, US-China and India-China using Fractionally Integrated VECM to study co-integration between them. By complementing the model with a multivariate GARCH model, it was observed that all these pairs are fractionally co-integrated. The US market played a leading position at the same time as there remained an interactive relationship between US and Chinese stock markets, as supported in Saha and Bhunia (2012). Hoque (2007) explored the dynamics of stock price movements of an emerging market such as Bangladesh with that of USA, Japan and India using daily closing price data starting from January 1, 1990 to December 31, 2000. The index utilized for Bangladesh, India, Japan and USA were Dhaka Stock Exchange (DSE) All Share Price Index, BSE30, Nikkei 225 and S\&P500 in that order. They examined the long-run associations among the markets using the Johansen multivariate co-integration approach and short-term dynamics were captured through vector error correction models. Vector Auto Regression was employed to investigate the impact of shocks of these markets on own markets and other markets. The testing demonstrated that there was support of long term co-integration among the markets suggesting that stock prices in the countries share a common stochastic trend. Impulse response analysis shows that shocks to US market do have an impact on Bangladesh stock market. The response of Bangladesh stock market to shocks Indian stock market is weak. Shocks to Japanese stock market do not generate a response in the Bangladesh stock market, as supported in Joshi (2011). Raj and Dhal (2008) observe that the Indian market's dependence on global markets, such as the US and the UK, is substantially higher than on regional markets such as Singapore and Hong Kong. Majid et al. (2008) find long-run relationships for five ASEAN countries with the US and Japan only in the post-crisis period, while Awokuse et al. (2009) evidenced that the number of co integrating vectors increases in the post-crisis period among 11 Asian economies. Ismail and Rah man (2009) investigated the relationship between the US and four leading Asian emerging stock markets namely Hong Kong, India, South Korea and Malaysia and found that there were possibilities of relationship between all the stock markets. Long staff's (2010) empirical investigation into the pricing of subprime asset-backed collateralized debt obligations (CDOs) and their contagion effects on other markets find strong evidence of contagion in the financial markets. Kim et al. (2010) studied the turmoil of 2007-2009 and found how the troubles in a small segment of the US mortgage market became escalated into a crisis of global proportions. Yilmaz (2010) examines the extent of contagion and interdependence across the East Asian equity markets since early 1990s and compares the ongoing crisis with earlier episodes. They show that there is substantial difference between the behaviour of the East Asian return and volatility spillover indices over time. While the return spill over index reveals increased integration among the East Asian equity 


\section{American Research Journal of Humanities and Social Sciences, Volume 1, Issue1, Feb-2015}

ISSN 2378-7031

markets, the volatility spill over index experiences significant bursts during major market crises, including the East Asian crisis. Fidrmuc and Korhonen (2010) analyze the transmission of global financial crisis to business cycles in China and India. They find wide differences for different frequencies of cyclical development. More specifically, at business cycle frequencies, dynamic correlations are typically low or negative, but they are influenced most by the global financial crisis. Finally, they locate a noteworthy connection between trade ties and dynamic correlations of GDP growth rates in emerging Asian countries and OECD countries. The continuation of selected variables about stock market in India is survived or not especially subsequent to international financial crises, Indian political condition and the impact of the rupee depreciation. On these arguments this research paper investigates the impact of selected eight countries stock market index on BSE-Sensex in India.

\section{Methodology}

The present research work is based on secondary data source consisting of daily data collected from Yahoo.Com database and index mundi database designed for 1991 to 2013. This research work considers nine countries stock price indices, that is to say, HKSE, JKSE, KLSE, KOSPI, KSE, NIKKEI, SSE, TSEC and SENSEX of Bombay stock exchange (the closing price) have been taken for the preferred periods. The entire empirical test has been prepared by using econometric (Eviews 7) software. Primarily all the preferred variables are converted into natural logarithm due to its non-uniformity status. To investigate, descriptive statistics, correlation statistics, test of stationary through ADF unit root test, Johansen co-integration test and pair wise Granger causal test method have been employed in the present research work.

Descriptive statistics contain the portrait of mean, median, standard deviation; kurtosis, skewness and J-B statistics with probability for the selected stock market indices that are exposed in Table 1. It is viewed that mean and standard deviation of the particular series have highest mean. Skewness, kurtosis and Jarque-Bera statistic with probability designates that none of the series are normally distributed.

Table1. Descriptive Statistics

\begin{tabular}{|c|c|c|c|c|c|c|c|c|c|}
\hline & BSE & HKSE & JKSE & KLSE & KOSPI & KSE & NIKKEI & SSE & TSEC \\
\hline Mean & 9.42 & 9.81 & 7.62 & 7.08 & 7.27 & 9.23 & 9.36 & 7.68 & 8.86 \\
\hline Median & 9.64 & 9.90 & 7.76 & 7.14 & 7.39 & 9.27 & 9.32 & 7.70 & 8.90 \\
\hline Maximum & 10.12 & 10.36 & 8.56 & 7.54 & 7.71 & 10.30 & 9.81 & 8.71 & 9.19 \\
\hline Minimum & 7.98 & 9.04 & 5.99 & 6.44 & 6.29 & 7.90 & 8.86 & 6.92 & 8.32 \\
\hline Std. Dev. & 0.51 & 0.26 & 0.67 & 0.28 & 0.34 & 0.49 & 0.23 & 0.39 & 0.18 \\
\hline Skewness & -0.98 & -0.68 & -0.46 & -0.17 & -0.86 & -0.25 & 0.23 & 0.19 & -0.75 \\
\hline Kurtosis & 2.81 & 2.66 & 2.11 & 1.81 & 2.57 & 2.99 & 1.88 & 2.58 & 3.06 \\
\hline Jarque-Bera & 445.85 & 227.9 & 189.77 & 174.7 & 361.49 & 28.40 & 170.04 & 37.12 & 256.92 \\
\hline Probability & 0.00 & 0.00 & 0.00 & 0.00 & 0.00 & 0.00 & 0.00 & 0.00 & 0.00 \\
\hline
\end{tabular}

Correlation statistics in table2 reveal that BSE-Sensex and all the selected stock market indices are positively correlated under the study nonetheless it does not talk about the justification and shock in terms of causality (Bhunia, 2013). With the intention of imply an undeniable explanation of the shock; it is requisite to perform Johansen co-integration and Granger causality test between the selected variables.

Table2. Correlation Statistics

\begin{tabular}{|c|c|c|c|c|c|c|c|c|c|}
\hline & BSE & HKSE & JKSE & KLSE & KOSPI & KSE & NIKKEI & SSE & TSEC \\
\hline BSE & 1.00 & & & & & & & & \\
\hline HKSE & 0.94 & 1.00 & & & & & & & \\
\hline JKSE & 0.95 & 0.87 & 1.00 & & & & & & \\
\hline KLSE & 0.92 & 0.87 & 0.97 & 1.00 & & & & & \\
\hline KOSPI & 0.98 & 0.93 & 0.96 & 0.93 & 1.00 & & & & \\
\hline KSE & 0.88 & 0.84 & 0.88 & 0.90 & 0.88 & 1.00 & & & \\
\hline NIKKEI & 0.15 & 0.28 & 0.03 & 0.10 & 0.16 & 0.40 & 1.00 & & \\
\hline SSE & 0.68 & 0.76 & 0.60 & 0.60 & 0.66 & 0.46 & -0.01 & 1.00 & \\
\hline TSEC & 0.82 & 0.88 & 0.78 & 0.83 & 0.84 & 0.78 & 0.39 & 0.64 & 1.00 \\
\hline
\end{tabular}




\section{EMPIRICAL RESULTS AND ANALYSIS}

\subsection{Results of Unit root test}

Johansen co-integration and Granger causal test is crucial wherever there is any underlying shock of selected variables on BSE-sensex. This test is accessible if the series are stationary. With the purpose of stationary investigation, unit root tests of Augmented Dickey-Fuller (ADF) by way of intercept as well as intercept and trend are performed with the levels and first differences of each variables on the stipulation that the null hypothesis is nonstationary, afterward refusal of the unit root hypothesis support stationary.

Table $3 \& 4$ shows the results of unit root test. It reveals that time series are not stationary at levels in both the test equations of intercept and intercept \& trend. However, table shows that the various countries' stock market indices and BSE-sensex are stationary at 1st difference in both the test equations of intercept and intercept \& trend [1(1)]. Augmented Dickey Fuller unit root analysis test divulges that errors have constant variance and are statistically independent. Consequently, Johansen cp-integration and Granger causal test can be applied on these variables, as supported in (Shahzadi and Chohan, 2012) and Kaliyamoorthy and Parithi (2012).

Table3. ADF Unit Root Test Results at levels and Intercept

\begin{tabular}{|c|c|c|c|c|c|c|c|c|c|}
\hline & BSE & HKSE & JKSE & KLSE & KOSPI & KSE & NIKKEI & SSE & TSEC \\
\hline \multirow{2}{*}{ t-stat. } & -2.34 & -2.70 & -2.28 & -1.59 & -2.81 & -1.54 & -1.90 & -1.29 & -2.62 \\
& $(0.16)$ & $(0.07)$ & $(0.18)$ & $(0.49)$ & $(0.06)$ & $(0.51)$ & $(0.33)$ & $(0.64)$ & $(0.09)$ \\
\hline $5 \%$ & -2.86 & -2.86 & -2.86 & -2.86 & -2.86 & -2.86 & -2.86 & -2.86 & -2.86 \\
\hline Rem. & NS & NS & NS & NS & NS & NS & NS & NS & NS \\
\hline
\end{tabular}

MacKinnon (1996) one-sided p-values.

NS stands for non-stationary and S stands for stationary

\begin{tabular}{|c|c|c|c|c|c|c|c|c|c|}
\hline & BSE & HKSE & JKSE & KLSE & KOSPI & KSE & NIKKEI & SSE & TSEC \\
\hline \multirow{2}{*}{ t-stat. } & -49.28 & -54.59 & -46.9 & -57.9 & -51.70 & -46.1 & -54.68 & -53.2 & -49.8 \\
& $(0.00)$ & $(0.00)$ & $(0.00)$ & $(0.00)$ & $(0.00)$ & $(0.00)$ & $(0.00)$ & $(0.00)$ & $(0.00)$ \\
\hline $5 \%$ & -2.86 & -2.86 & -2.86 & -2.86 & -2.86 & -2.86 & -2.86 & -2.86 & -2.86 \\
\hline Rem. & S & S & S & S & S & S & S & S & S \\
\hline
\end{tabular}

Table4.ADF Unit Root Test Results at 1st differences and intercept

MacKinnon (1996) one-sided p-values.

\subsection{Results of Multivariate Co-integration Test}

Since eight countries stock market index and BSE-Sensex are stationary, therefore, multivariate co-integration method in Johansen approach can be applied to detect the co-integration affiliation between the variables in the long period. At the same time, this method can be determined the co-integration vectors. As we know, two likelihood ratios, to be precise, the Trace Test and the Maximum Eigen Value test can resolve the co-integration vectors. At the same time, this research work presupposes linear deterministic trend unrestricted with intercepts without trends on account of using a lag of 1 to 4 at 1st differences derived from AIC for the selected commodity and stock market indicators under the study.

Table-5 exhibits the multivariate co-integration test results through Johansen approach that gives surety about affiliation between eight countries stock market index and stock market index of Bombay stock exchange in the long period because trace statistics is more than critical value in case of both the likelihood ratio test, that is, the trace test and the maximum eigenvalue test. Consequently, the multivariate co-integration test results do not accept the null hypothesis (mentioned in hypothesis-2 above). This test also confirmed the number (four) of co-integration vectors. It is furthermore indicating that four common stochastic trends or a degree of market integration are pres

Table5. Results of Multivariate Co-integration Test

\begin{tabular}{|c|c|c|c|c|}
\hline \multicolumn{5}{|c|}{ Unrestricted Co-integration Rank Test (Trace) } \\
\hline Hypothesized & & Trace & 0.05 & \\
\hline No. of CE(s) & Eigen value & Statistic & Critical Value & Prob.** \\
\hline None $*$ & 0.052457 & 374.1467 & 197.3709 & 0.0000 \\
\hline At most $1 *$ & 0.026625 & 225.4312 & 159.5297 & 0.0000 \\
\hline
\end{tabular}


American Research Journal of Humanities and Social Sciences, Volume 1, Issue1, Feb-2015 ISSN 2378-7031

\begin{tabular}{|c|c|c|c|c|}
\hline At most $2 *$ & 0.019769 & 150.9511 & 125.6154 & 0.0006 \\
\hline At most $3 *$ & 0.014110 & 95.84188 & 95.75366 & 0.0493 \\
\hline At most 4 & 0.008782 & 56.61992 & 69.81889 & 0.3535 \\
\hline At most 5 & 0.006634 & 32.27542 & 47.85613 & 0.5970 \\
\hline At most 6 & 0.002520 & 13.90526 & 29.79707 & 0.8459 \\
\hline At most 7 & 0.001501 & 6.941150 & 15.49471 & 0.5845 \\
\hline At most 8 & 0.001012 & 2.795911 & 3.841466 & 0.0945 \\
\hline \multicolumn{5}{|c|}{ Trace test indicates 4 co-integrating equation(s) at $5 \%$ level } \\
\hline \multicolumn{5}{|c|}{$*$ denotes rejection of the hypothesis at $5 \%$ level } \\
\hline \multirow{2}{*}{\multicolumn{5}{|c|}{$\begin{array}{c}* * \text { MacKinnon-Haug-Michel is (1999) p-values } \\
\text { Unrestricted Co-integration Rank Test (Maximum Eigenvalue) }\end{array}$}} \\
\hline & & & & \\
\hline Hypothesized & & Max-Eigen & 0.05 & \\
\hline No. of $\mathrm{CE}(\mathrm{s})$ & Eigen value & Statistic & Critical Value & Prob.** \\
\hline None * & 0.052457 & 148.7156 & 58.43354 & 0.0000 \\
\hline At most $1 *$ & 0.026625 & 74.48010 & 52.36261 & 0.0001 \\
\hline At most $2 *$ & 0.019769 & 55.10921 & 46.23142 & 0.0044 \\
\hline At most 3 & 0.014110 & 39.22195 & 40.07757 & 0.0622 \\
\hline At most 4 & 0.008782 & 24.34450 & 33.87687 & 0.4307 \\
\hline At most 5 & 0.006634 & 18.37016 & 27.58434 & 0.4646 \\
\hline At most 6 & 0.002520 & 6.964108 & 21.13162 & 0.9553 \\
\hline At most 7 & 0.001501 & 4.145239 & 14.26460 & 0.8437 \\
\hline At most 8 & 0.001012 & 2.795911 & 3.841466 & 0.0945 \\
\hline \multicolumn{5}{|c|}{ Max- Eigen value test indicates 3 co-integrating equation(s) at $5 \%$ level } \\
\hline \multicolumn{5}{|c|}{$*$ denotes rejection of the hypothesis at $5 \%$ level } \\
\hline \multicolumn{4}{|c|}{ **MacKinnon-Haug-Michel is (1999) p-values } & \\
\hline
\end{tabular}

\subsection{Results of Granger causality Tests}

The Granger causality test (Awe, 2012) is a statistical proposal test designed for influential whether one time series is supportive for prediction any more. This test has been prepared in the present study in pursue for the movement of causation between selected countries stock market index and sensex.

Table-6 delineations to facilitate no causality and bi-directional causality survive between selected eight countries stock market index and BSE-sensex under the study. Bi-directional causality exists between the selected variables in 30 cases because the probability is less than 0.05 and obviously the null hypothesis is rejected. No causality exists between the selected variables in 42 cases because the probability is more than 0.05 and the null hypothesis is not rejected. It is important that the effect of causality between the particular indicators does not mean that movement in one indicator basically causes movements in another indicator. To a huge exposure, causality fundamentally guides to the associations of the time series (Awe, 2012).

Table6. Results of Granger Causality Tests

\begin{tabular}{|c|c|c|c|c|}
\hline Null Hypothesis: & Obs & F-Stat & Prob. & \\
\hline HKSE $\uparrow \mathrm{BSE}$ & 2806 & 0.74 & 0.4774 & \\
\hline \multicolumn{2}{|l|}{ BSE $\uparrow \mathrm{HKSE}$} & 11.19 & 1.E-05 & Bi-directional causality \\
\hline JKSE $\uparrow$ BSE & 2763 & 9.98 & 5.E-05 & Bi-directional causality \\
\hline \multicolumn{2}{|l|}{ BSE $\uparrow \mathrm{JKSE}$} & 0.12 & 0.8887 & \\
\hline KLSE $\uparrow \mathrm{BSE}$ & 2801 & 4.08 & 0.0170 & Bi-directional causality \\
\hline \multicolumn{2}{|l|}{ BSE $\uparrow \mathrm{KLSE}$} & 1.99 & 0.1373 & \\
\hline KOSPI $\uparrow \mathrm{BSE}$ & 2806 & 16.05 & 1.E-07 & Bi-directional causality \\
\hline \multicolumn{2}{|l|}{ BSE $\uparrow$ KOSPI } & 10.38 & 3.E-05 & Bi-directional causality \\
\hline $\mathrm{KSE} \uparrow \mathrm{BSE}$ & 2801 & 1.56 & 0.2099 & \\
\hline \multicolumn{2}{|l|}{$\mathrm{BSE} \uparrow \mathrm{KSE}$} & 5.13 & 0.0059 & Bi-directional causality \\
\hline NIKKEI $\uparrow$ BSE & 2789 & 1.75 & 0.1736 & \\
\hline \multicolumn{2}{|l|}{ BSE $\uparrow$ NIKKEI } & 1.30 & 0.2740 & \\
\hline SSE $\uparrow \mathrm{BSE}$ & 2806 & 0.40 & 0.6715 & \\
\hline
\end{tabular}


American Research Journal of Humanities and Social Sciences, Volume 1, Issue1, Feb-2015 ISSN 2378-7031

\begin{tabular}{|c|c|c|c|c|}
\hline \multicolumn{2}{|l|}{$\mathrm{BSE} \uparrow \mathrm{SSE}$} & 4.12 & 0.0163 & Bi-directional causality \\
\hline TSEC $\uparrow \mathrm{BSE}$ & 2805 & 3.90 & 0.0203 & Bi-directional causality \\
\hline \multicolumn{2}{|l|}{ BSE $\uparrow$ TSEC } & 5.23 & 0.0054 & Bi-directional causality \\
\hline JKSE $\uparrow$ HKSE & 2763 & 5.38 & 0.0046 & Bi-directional causality \\
\hline \multicolumn{2}{|l|}{ HKSE $\uparrow \mathrm{JKSE}$} & 6.85 & 0.0011 & Bi-directional causality \\
\hline KLSE $\uparrow \mathrm{HKSE}$ & 2801 & 5.87 & 0.0028 & Bi-directional causality \\
\hline \multicolumn{2}{|l|}{ HKSE $\uparrow$ KLSE } & 2.54 & 0.0787 & \\
\hline KOSPI $\uparrow \mathrm{HKSE}$ & 2815 & 15.23 & 3.E-07 & Bi-directional causality \\
\hline \multicolumn{2}{|l|}{ HKSE $\uparrow$ KOSPI } & 0.04 & 0.9633 & \\
\hline KSE $\uparrow \mathrm{HKSE}$ & 2801 & 2.30 & 0.1003 & \\
\hline \multicolumn{2}{|l|}{ HKSE $\uparrow \mathrm{KSE}$} & 0.32 & 0.7295 & \\
\hline NIKKEI $\uparrow$ HKSE & 2789 & 2.53 & 0.0802 & \\
\hline \multicolumn{2}{|l|}{ HKSE $\uparrow$ NIKKEI } & 1.52 & 0.2192 & \\
\hline SSE $\uparrow \mathrm{HKSE}$ & 2840 & 1.90 & 0.1495 & \\
\hline \multicolumn{2}{|l|}{ HKSE $\uparrow$ SSE } & 3.08 & 0.0459 & Bi-directional causality \\
\hline TSEC $\uparrow \mathrm{HKSE}$ & 2805 & 17.47 & 3.E-08 & Bi-directional causality \\
\hline \multicolumn{2}{|l|}{ HKSE $\uparrow$ TSEC } & 0.47 & 0.6257 & \\
\hline KLSE $\uparrow \mathrm{JKSE}$ & 2763 & 0.18 & 0.8330 & \\
\hline \multicolumn{2}{|l|}{ JKSE $\uparrow$ KLSE } & 9.39 & 9.E-05 & Bi-directional causality \\
\hline KOSPI $\uparrow$ JKSE & 2763 & 2.14 & 0.1184 & \\
\hline \multicolumn{2}{|l|}{ JKSE $\uparrow$ KOSPI } & 12.77 & 3.E-06 & Bi-directional causality \\
\hline KSE $\uparrow J K S E$ & 2763 & 0.07 & 0.9334 & \\
\hline \multicolumn{2}{|l|}{ JKSE $\uparrow \mathrm{KSE}$} & 1.77 & 0.1703 & \\
\hline NIKKEI $\uparrow \mathrm{JKSE}$ & 2763 & 4.34 & 0.0131 & Bi-directional causality \\
\hline \multicolumn{2}{|l|}{ JKSE $\uparrow$ NIKKEI } & 0.06 & 0.9438 & \\
\hline SSE $\uparrow J K S E$ & 2763 & 0.23 & 0.7983 & \\
\hline \multicolumn{2}{|l|}{ JKSE $\uparrow$ SSE } & 0.51 & 0.6000 & \\
\hline$\overline{T S E C} \uparrow \mathrm{JKSE}$ & 2763 & 4.63 & 0.0098 & Bi-directional causality \\
\hline \multicolumn{2}{|l|}{$\overline{J K S E} \uparrow$ TSEC } & 3.69 & 0.0251 & Bi-directional causality \\
\hline KOSPI $\uparrow$ KLSE & 2801 & 2.17 & 0.1148 & \\
\hline \multicolumn{2}{|l|}{ KLSE $\uparrow$ KOSPI } & 13.17 & 2.E-06 & Bi-directional causality \\
\hline KSE $\uparrow \mathrm{KLSE}$ & 2801 & 0.07 & 0.9289 & \\
\hline \multicolumn{2}{|l|}{ KLSE $\uparrow \mathrm{KSE}$} & 4.77 & 0.0086 & Bi-directional causality \\
\hline NIKKEI $\uparrow$ KLSE & 2789 & 0.31 & 0.7364 & \\
\hline \multicolumn{2}{|l|}{ KLSE $\uparrow$ NIKKEI } & 0.16 & 0.8492 & \\
\hline SSE $\uparrow \mathrm{KLSE}$ & 2801 & 0.62 & 0.5372 & \\
\hline \multicolumn{2}{|l|}{ KLSE $\uparrow \mathrm{SSE}$} & 0.56 & 0.5740 & \\
\hline TSEC $\uparrow$ KLSE & 2801 & 18.33 & 1.E-08 & Bi-directional causality \\
\hline \multicolumn{2}{|l|}{ KLSE $\uparrow$ TSEC } & 4.02 & 0.0180 & Bi-directional causality \\
\hline KSE $\uparrow$ KOSPI & 2801 & 1.16 & 0.3128 & \\
\hline KOSPI $\uparrow ~ K S E$ & & 0.83 & 0.4346 & \\
\hline NIKKEI $\uparrow$ KOSPI & 2789 & 0.57 & 0.5675 & \\
\hline KOSPI $\uparrow$ NIKKEI & & 0.88 & 0.4155 & \\
\hline SSE $\uparrow$ KOSPI & 2815 & 1.06 & 0.3456 & \\
\hline KOSPI $\uparrow \mathrm{SSE}$ & & 2.20 & 0.1106 & \\
\hline TSEC $\uparrow$ KOSPI & 2805 & 7.19 & 0.0008 & Bi-directional causality \\
\hline KOSPI $\uparrow$ TSEC & & 30.40 & 9.E-14 & Bi-directional causality \\
\hline NIKKEI $\uparrow$ KSE & 2789 & 0.71 & 0.4941 & \\
\hline KSE $\uparrow$ NIKKEI & & 0.99 & 0.3705 & \\
\hline SSE $\uparrow \mathrm{KSE}$ & 2801 & 1.09 & 0.3356 & \\
\hline $\mathrm{KSE} \uparrow \mathrm{SSE}$ & & 0.62 & 0.5381 & \\
\hline TSEC $\uparrow \mathrm{KSE}$ & 2801 & 3.57 & 0.0283 & Bi-directional causality \\
\hline KSE $\uparrow \mathrm{TSEC}$ & & 1.96 & 0.1410 & \\
\hline
\end{tabular}


American Research Journal of Humanities and Social Sciences, Volume 1, Issue1, Feb-2015 ISSN 2378-7031

\begin{tabular}{|c|c|c|c|c|}
\hline SSE $\uparrow ~ N I K K E I$ & 2789 & 3.91 & 0.0201 & Bi-directional causality \\
\hline \multicolumn{2}{|l|}{ NIKKEI $\uparrow$ SSE } & 5.67 & 0.0035 & Bi-directional causality \\
\hline TSEC $\uparrow$ NIKKEI & 2789 & 0.29 & 0.7468 & \\
\hline \multicolumn{2}{|l|}{ NIKKEI $\uparrow$ TSEC } & 1.99 & 0.1370 & \\
\hline TSEC $\uparrow$ SSE & 2805 & 4.80 & 0.0083 & Bi-directional causality \\
\hline \multicolumn{2}{|l|}{ SSE $\uparrow$ TSEC } & 0.39 & 0.6744 & \\
\hline
\end{tabular}

Note: Decision rule: reject H0 if P-value $<0.05, \mathrm{DNR}=$ Do not reject; $\uparrow=$ does not Granger cause.

\section{CONClusion}

The present study investigates the relationship between selected Asian eight countries stock market index and Indian stock market BSE-Sensex. The primary findings of the study is that the time series data is non-stationary at levels but stationary at $\mathrm{I}(1)$ that is an indication of Johansen co-integration test and Granger pair wise causality test. Johansen multivariate co-integration test shows that Indian stock market index is associated with selected other emerging stock market index over a twenty year periods, which indicates Indian stock markets, is influenced by selected stock market index during the study period or vice-versa. Again, Granger causality test illustrates that bidirectional causality exists between the selected variables in 30 cases out of 72 cases between the selected stock market indices. These results are identical with the policy decisions of the Indian economy because Indian stock market is directly or indirectly influenced by the selected Asian countries stock market or their economic policy decisions.

\section{REFERENCES}

[1] Abas, M. (2009). Analysis of Stock Market Linkages: Chinese, Indian and Major Markets, Unpublished Dissertation.

[2] Ahmad,Ashraf and Ahmed. (2005). Is the Indian Stock Market Integrated with the US and Japanese Markets?, An Empirical Analysis, South Asia Economic Journal, 6(2), 193-206.

[3] Aktan, B., Mandaci, P. V., Kopurla. B. S. and Ersener. B. (2009). Behaviour of Emerging Stock Markets in the Global Financial Meltdown: Evidence from BRIC-A, African Journal of Business Management. 3 (9), 1-16.

[4] Awe, O. O (2012) On Pairwise Granger causality Modelling and Econometric Analysis of Selected Economic Indicators. Interstat statjournals.net/YEAR/2012/articles/1208002.pdf.

[5] Awokuse, T. O., Chopra, A., and Bessler, D. A. (2009). Structural change and international stock market interdependence: Evidence from Asian emerging markets, Economic Modelling. 26.

[6] Bailey, W. and Stulz, R. M. (1990). Benefits of International Diversification: The Case of Pacific Basin Stock Markets. Journal of Portfolio Management, 16, 57-61.

[7] Bose, S. (2005). Securities Market Regulations: Lessons from US and Indian Experience. The ICRA Bulletin of Money \& Finance, 2, 20-37.

[8] Bhattacharya and Samanta. (2001). A tale of two indices: the story of the NASDAQ and The Sensex, Journal of Quantitative Economics, 1(1), 89-102.

[9] Bhunia, A. (2013). Co-integration and Causal Relationship among Crude Price, Domestic Gold Price and Financial Variables-An Evidence of BSE and NSE. Journal of Contemporary Issues in Business Research, 2(1), 1-10.

[10] Chattopadhyay, S.K. and Behera, S.R. (2006). Financial Integration for Indian Stock Market, Working Paper, 8th Annual Conference on Money and Finance in the Indian Economy, IGIDR, 1-29, taken online from http://www.slideshare.net/Zorro29/financial-integration-for-indian-stock-market

[11] Chen, H., Lobo, J. B., and Wong, W-K. (2006). Links between the Indian, US and Chinese Stock Markets, Working Paper No. 0602.

[12] Eun and Shim. (1989), International Transmission of Stock Market Movements", Journal of Financial and Quantitative Analysis, Vol. 24(2), 241-255.

[13] Fidrmuc, J. and I. Korhonen. (2010). The Impact of the Global Financial Crisis on Business Cycles in the Emerging Economies in Asia, Journal of Asian Economics, 21,

[14] Harper, A, Zenhu, J and Gregory, G. (2013). Do These Stock Markets Move Together? an Empirical Study of India and Its Major Trading Partners, Academy of Accounting and Financial Studies Journal, 17(3), taken online from https://www.questia.com/library/journal/1G1-353105967/do-these-stock-markets-move-together-an-empirical.

[15] Hafiz, Al Asad Bin Hoque. (2007). Co- movement of Bangladesh stock market with other markets: Co-integration and error correction approach, Managerial Finance, 33(10), 810 - 820.

[16] Ismail, M. T. and Rahman, R. A. (2009), Modelling the Relationships between US and Selected Asian Stock Markets, World Applied Sciences Journal, 7 (11). 


\section{American Research Journal of Humanities and Social Sciences, Volume 1, Issue1, Feb-2015 ISSN 2378-7031}

[17] Joshi, P. (2011). Market Integration of Indian Stock Market- A Study of NSE, International Journal of Research in Commerce and Management, 1(6), 36-41.

[18] Kaliyamoorthy, S and Parithi, S. (2012.) Relationship of Gold Market and Stock Market: An Analysis, International Journal of Business and Management Tomorrow, 2(6).

[19] Kearney, C. \& Lucey, B.M. (2004). International Equity Market Integration: Theory, Evidence and Implications, International Review of Financial Analysis. Vol.13. no. 5.

[20] Kim S.J, Moshirian F. Wu, E. (2005). Dynamic Stock Market Integration Driven by the European Monetary Union: An Empirical Analysis, J. Bank, Finance, 29.

[21] Lamba, A.S. (2005). An Analysis of the Short- and Long-Run Relationships between South Asian and Developed Equity Markets. International Journal of Business. Vol. 10(4).

[22] Longstaff, F.A.(2010). The subprime credit crisis and contagion in Financial markets. Journal of Financial Economics, 97 , 436-450.

[23] Madhusoodhan, P. R. (2010). EVALUATION OF VARIOUS THEORETICAL CONCEPTS OF MARKET INTEGRATION AND INTERLINKAGES BETWEEN THE FOREIGN EXCHANGE MARKET AND THE STOCK MARKET, taken online from http://shodhganga.inflibnet.ac.in:8080/jspui/bitstream/10603/893/10/10_chapter\%203.pdf

[24] Majid, M. S. A., Meera, A. K. M., Omar, M. A. and Aziz, H. A. (2009), Dynamic Linkages Among ASEAN-5 Emerging Stock Markets, International Journal of Emerging Markets, 4(2).

[25] Raj, J. and Dhal, S. (2008). Integration of India’s Stock Market with Global and Major Regional Markets. BIS Papers, No. 42.

[26] Saha, M and Bhunia, A. (2012). How far India has gone down the road towards financial integration with US since subprime crisis? An Econometric Analysis, taken online from http://mpra.ub.uni-muenchen.de/38731/1/MPRA_paper_38731.pdf

[27] Shahzadi Hina, Chohan MN (2012) Impact of Gold Prices on Stock Exchange: A Case Study of Pakistan, Working paper series, Karachi Stock Exchange, 10 (2):1-12.

[28] Wong, Aman Agarwal \& Jun Du. (2005). Financial Integration for India Stock Market, a Fractional Co-integration Approach, Departmental Working Papers wp0501, National University of Singapore, Department of Economics.

[29] Yilmaz, K. (2010). Return and Volatility Spillovers among the East Asian Equity Markets, Journal of Asian Economics, 21(3). 